\title{
VIRGIL’S AMBIVALENCE TOWARDS OCTAVIAN
}

\begin{abstract}
Summary: There is a clear link between Virgil's Ecl. 1 and the ending of the Georgics, suggested by the quotation of Ecl. 1. 1 at Georg. 4. 566. Common to the two texts is a dualistic structure, in Ecl. 1 between the different situations of Tityrus and Meliboeus, and in Georg. 4. 559-566 between the different choices of life by Octavian and the poet. But the two texts are also linked by the figure of Octavian, in Ecl. 1 iuvenis deus, but also responsible for the land eviction suffered by Meliboeus, at Georg. 4. 560-562 thundering and shining god, opposite to Virgil's leisure. It is a symptom of a constantly ambivalent attitude of Virgil towards him, confirmed once again at the end of the Aeneid: here in a new dualism (Aeneas/Turnus, mercy/vengeance) we find a figure (the hero) and a theme (revenge) closely related to Octavian. So these key-points of his poetry offer an opportunity to reflect on the range and limits of Virgil's consent to the Augustan regime.
\end{abstract}

Key words: ambivalence in Virgil's poetry; dualism; sympathy for the defeated; Octavian and Virgil

The polysemy and the ambivalence of Virgil's poetry and its vagueness in references to current events have often led scholars to discern underlying ambiguities and criticism in the attitude of the poet towards Octavian and in the representation of him in his work. ${ }^{1}$ This subject, a matter of interest also in recent years, especially in the interpretation of the Georgics, in which the future princeps appears several times, has given rise to different positions: to some critics Octavian has appeared the chief 'pupil' to whom the poet gives his teaching for a wise and just government, but to whom he also reserves warnings and perhaps vague threats; ${ }^{2}$ on the contrary, others maintain the sincere and total support of Virgil to Octavian's pars, reading his entire work as a

\footnotetext{
${ }^{1}$ This is, among the others, the attitude of the so called "Harvard school"; contra, PoweLL, A.: Virgil the Partisan. A study in the re-integration of Classics. Swansea 2008, 10-12.

${ }^{2}$ See the volume of NAPPA, CHR.: Reading after Actium. Vergil's Georgics, Octavian and Rome. Ann Arbor 2005.
} 
skilled and broad defence of the heir of Caesar over the confused and difficult years of his achievement and in the early days of his regime. ${ }^{3}$

In almost every reference to Octavian in the Georgics lurks the possibility of double meanings or ambiguous words, chiefly in the passages likely written after Actium and perhaps after the conquest of Egypt, by which time the young Caesar was the undisputed winner. ${ }^{4}$ The only exception might be Georg. 1. 498-501:

\section{Di patrii Indigetes et Romule Vestaque mater, quae Tuscum Tiberim et Romana Palatia servas, hunc saltem everso iuvenem succurrere saeclo ne prohibete.}

O tutelary gods of Rome, and you, Romulus, and mother Vesta, who protect Tuscan Tiber and Rome's Palatine, do not forbid that this young man save our fallen generation.

Here the anguished tone and the apocalyptical athmosphere reveal the actual fright of his contemporaries at current events and their possible outcome, and show the hopes placed on the young heir of the dictator.

In other places where Octavian appears, the tone is different, and the emphasis sometimes excessive, especially on the subject of deification, at the beginning and conclusion of the poem (see Georg. 1. 24-42 and 4. 560-562), but also in the frame of the second half. The wide proem of the third book corresponds in fact to the final appearance of the winner lightening in the East, at Georg. 4. 560-562, with the announcement of his future celebration. This attitude of Virgil has been read as a warning to the future princeps against exceeding human limits and running the risk of becoming a tyrant. ${ }^{5}$ Conversely, in the same pieces a certain irony about the excesses of Octavian's propaganda is seen: so at Georg. 1. 31 the reference to an imaginary marriage of him with a sea-goddess ${ }^{6}$ (teque sibi generum Tethys emat omnibus undis, "and Tethys forfeits all her waves to have you as a son-in law") could hint at Sextus Pompeius, ruler of the seas and his dreadful opponent. ${ }^{7}$ The concealed identification of Octavian with Jupiter, or even his replacement for the father of the gods, also appears baffling: Jupiter is in fact remarkably absent in the invocations that begin the

\footnotetext{
${ }^{3}$ This is the position of POWELL (n. 1).

${ }^{4}$ See Georg. 1. 24-43. On the probable composition at the time of the publication of the poem, see Virgil, Georgics. Vol. I: Books I-II. Edited by R. F. THOMAS. Cambridge 1988, ad Georg. 1. 24-42, p. 73; Georg. 2. 171-172, dating back very likely to $30 / 29$ for its allusion to the Egyptian campaign of Octavian (see Hollis, A. S.: Octavian in the Fourth Georgics. CQ 46 [1996] 305-308, esp. 306, n. 2); Georg. 3. 148 , which because of his references to operations in the East and to the triple triumph of Octavian in 29 cannot be earlier than this date (see Virgil, Georgics. Vol. II: Books III-IV. Edited by R. F. THOMAS. Cambridge 1988 ad Georg. 3. 1-48, p. 36); the same chronological reasons apply to Georg. 4. 516-566, which also alludes to the campaign of the future princeps in the East.

${ }^{5}$ NAPPA (n. 2).

${ }^{6}$ About the possible irony of this passage see Hollis (n. 4) 307, n. 9.

${ }^{7}$ On the subject, see the careful investigation of POWELL (n. 1) esp. 16-24, 31-131, 133-147, 183-197, 283-290.
} 
poem, and at 4. 560-561 (Caesar dum magnus ad altum / fulminat Euphraten, "while the great Caesar lightens in war by the deep Euphrates") Octavian seems to take on his distinctive features. ${ }^{8}$ Allusions, moreover, to the future Augustus in the laudes Italiae at Georg. 2. 161-164 could conceal criticism and irony about him:

an memorem portus Lucrinoque addita claustra atque indignatum magnis stridoribus aequor, Iulia qua ponto longe sonat unda refuso Tyrrhenusque fretis immittitur aestus Avernis?

Shall I recall the harbors and the barrier thrown across the Lucrine, and how the sea roars aloud in wrath, where the Julian wave resounds afar when the sea is flung back and the Tyrrhenian tide pours into the current of Avernus?

Here the reference to the great works of engineering in the lakes Lucrine and Avernus evokes again the terrible threat of Sextus Pompeius, ${ }^{9}$ and the debated mention of military operations in the East:

te, maxime Caesar, qui nunc extremis Asiae iam victor in oris imbellem avertis Romanis arcibus Indum.

you, great Caesar, who, having conquered the remote Asian shores, now keep the weak Indians away from the Roman fortresses.

This seems to mock Octavian's scarce military skills and the emphasis given to unimportant martial exploits. ${ }^{10}$

From this perspective, the final $\sigma \varphi \rho \alpha \gamma i$ s assumes particular importance:

Haec super arvorum cultu pecorumque canebam et super arboribus, Caesar dum magnus ad altum fulminat Euphraten bello victorque volentis per populos dat iura viamque adfectat Olympo.

Illo Vergilium me tempore dulcis alebat Parthenope studiis florentem ignobilis oti, carmina qui lusi pastorum audaxque iuventa, Tityre, te patulae cecini sub tegmine fagi. Georg. 4. 559-566

This I sang about the care of fields, of cattle and trees, while the great Caesar lightens in war by the deep Euphrates and as a winner gives laws to

\footnotetext{
${ }^{8}$ See Thomas I (n. 4), ad Georg. 1. 1-42, p. 68; ThOMAs II (n. 4) ad Georg. 4. 560-561 and 562, p. 240.

${ }^{9}$ See Powell (n. 1) 234-236.

${ }^{10}$ See ThOMAS I (n. 4) ad Georg. 2. 170-172, p. 189, and Hollis (n. 4) 307, n. 9, but formerly Serv. Auct. ad v. 172.
} 
willing nations, and prepares a path to heaven.

At that time the sweet Parthenope nursed me,

Virgil, and I flourished in a secluded rest and

joked with shepherds' songs; then in

my youth's boldness I sang about

you, Tityrus, reclining beneath the shelter of the beech tree.

Here the quasi-deified powerful lord, who magnus ad altum / fulminat Euphraten, unexpectedly approaches the figure of the poet in his only autobiographical reference, ${ }^{11}$ in which his name actually appears. He represents himself not as poet of Octavian's feasts, but as a symbol of a lifestyle opposite to him, devoted to otium and poetry. The uniqueness of these verses is obviously due to the quotation of Ecl. 1. 1 (Tityre, tu patulae... sub tegmine fagi, "beneath the shelter of a broad beech tree") in the last verse of the Georgics 4, which in turn suggests Georg. 2. 485-489, where even Virgil declared his inclination to the bucolic genre and to a secluded way of life (inglorius, 2. 486):

rura mihi et rigui placeant in vallibus amnes,

flumina amem silvasque inglorius. O ubi campi

Spercheosque et virginibus bacchata Lacaenis

Taygeta! o qui me gelidis convallibus Haemi

sistat, et ingenti ramorum protegat umbra!

May I love the waters and the woods, though unknown.

O for those plains and Spercheus and Taygetus, where

Spartan girls hold Bacchic rites! I hope that someone will

set me in the cold glens of Haemus and protect me in the

shadow of large branches!

This closure, however, contains not only a poetic discourse. The mention of Octavian shows glimpses of a political background and reveals the intention of the author to focus on him. The echo of Ecl. 1, in fact, is not only an allusion to the bucolic liber; this eclogue is also the only one in which Octavian appears - not named explicitly, but easily recognizable by his attributes of youth: hic illum vidi iuvenem, "I saw here that young man" (Ecl. 1. 42); divinity (O Meliboee, deus haec otia fecit, / namque erit ille mihi sempre deus, "O Meliboeus, a god has made this leisures for us, for that man forever will be a god to me", Ecl. 1. 6-8; neque servitio me exire licebat, / nec tam praesentis alibi cognoscere divos, "it was neither permitted for me leave from slavery, nor to know so powerful gods in another place", Ecl. 41-43) and power to decide the fate of Tityrus and others (ille meas errare boves ... et ipsum / ludere quae vellem calamo permisit agresti, "that man allowed my cows to roam ... and me to play the rustic reed pipe which I pluck up", Ecl. 1. 9-10; hic mihi responsum primus dedit ille petenti: / pascite ut ante boves, pueri, submittite tauros, "here he first gave

${ }^{11}$ Less verifiable appears to be, for example, the assertion of the poet that he himself has seen the garden of the senex Corycius, which is probably Virgil's invention: see THOMAS II (n. 4) ad Georg. 4. 125-127, p. 170. 
an answer to my demands: Graze your cattle as before, boys, rear your bulls" Ecl. 1 . 44-45). ${ }^{12}$ Recalling this image of Octavian in the $\sigma \varphi \rho \alpha \gamma i$ s at Georg. 4. 559-566, the poet clearly aims to establish a comparison between the two representations of the future princeps and to suggest some considerations.

In Ecl. 1 the young god who grants Tityrus freedom and ownership of his land is highly praised: his figure is placed in the exact center of the poem, and Tityrus declares to him eternal gratefulness, which will result in divine honours; the shepherd really calls him deus, with an emphasis reminiscent of Lucretius' enthusiasm for Epicurus or Mopsus' admiration for Daphnis at Ecl. 5. 64. ${ }^{13}$ But the other voice in the eclogue is that of Meliboeus, the dispossessed, symbol of the small owners despoiled of their land in favour of Octavian's veterans: he is the most pitiful and touching character. Octavian was regarded by the public as chiefly responsible for the grievous policy of confiscation: because he stayed in Italy, it was his task to manage confiscation - in a situation of diffused dissatisfaction - destined to result in the bellum Perusinum. ${ }^{14}$ And this loss of consent and sympathy could not be balanced by the limited exceptions he sometimes made (of these Tityrus is perhaps a symbol ${ }^{15}$ ): the poet's sympathy for Meliboeus, that appears through the treatment of the character and his feelings, gains a sympathetic response of the reader and makes him the real protagonist of the poem, in spite of the alleged identification of the author with Tityrus, as asserted by the ancient scholiasts. ${ }^{16}$ In this way, without taking a clear position on the delicate issue of confiscations, Virgil directs his (and reader's) sympathy to the dispossessed, evidently reflecting a common feeling and suggesting an underlying rebuke to the authors of the expropriations and their hardness to the veteres possessores. Of course, this impression is concealed and overshadowed by the praise of the young deus and by Tityrus' gratitude to him, but it is not completely dissipated: Tityrus after all is an exception in the upset landscape that surrounds him and that is instead the picture of the real situation. His lucky chance and peace jar with the fate of many owners forced to leave their world for an unknown fate, and this dramatic contrast is constantly emphasized by the 'us', by which Meliboeus refers to himself and his fellows in misfortune, as opposed to 'you', as used for Tityrus.

From the beginning of the Bucolics, Virgil presents the ambiguity of the historical situation in the years immediately following the death of Caesar and implies his own judgment on the protagonists of those events, primarily Octavian, in spite of

\footnotetext{
${ }^{12}$ In the debate about the identity of the iuvenis Powell (n. 1) 192-193 and 221, n. 31 seems to me decisive.

${ }^{13}$ The title of deus has been variously justified, or by being Octavian the adopted son of Caesar, deified after death, (this fact would give him the right to bear the same title of his father), or with the custom of the ancients to call deus a benefactor or a person of great consequence: see CADILI, L.: Viam adfectat Olympo. Memoria ellenistica nelle "Georgiche" di Virgilio. Milano 2001, 27-34; POWELL (n. 1) 192.

${ }^{14}$ About the situation at that time, a really hard period for Octavian in matter of popular support, cf. POWELL (n. 1) 183-185.

${ }_{16}^{15}$ POWELL (n. 1) 193-194.

${ }^{16}$ With great balance Serv. ad $E c l .1 .1$ rightly notes, however, that in reality only sometimes and in certain ways can Tityrus can be identified with Virgil. The observation of POWELL (n. 1) 193, that the poet is both in Tityrus and in Meliboeus is right.
} 
the alleged protection granted by him to the poet and the recovery of his land. Beyond his personal case (assuming that the poet's life story can be deduced from the $E_{c}$ logues), Virgil in this way gives utterance to public opinion and to the uncertainties and collective fears about the present and the future.

The figure of Octavian appeared necessarily ambiguous to his contemporaries. The violence in which he had shared in the first years of his power (think of the proscriptions, although the subsequent propaganda will try to ascribe them only to Anthony) remained in the memory and made people skeptical and cautious in their enthusiasm. It is significant - I think - that Virgil has placed in the opening of the collection, like the admonition not to forget, the theme of the confiscations and the figure of Octavian, whose role, while positive for Tityrus, does not cancel nor alleviate the drama of Meliboeus and the others who are dispossessed. His insertion into the eclogue sets off, with great caution, but also with great frankness, lights and shadows of Octavian, and inevitably recalls his decisive and unpleasant role in the expropriations.

The echo of just this eclogue, therefore, with all the implied themes that it evokes, in the conclusion of the Georgics is certainly not random. By reproposing of it to the then-young deus, but who by now has become the much-more-powerful master of the fates of entire peoples and responsible for the welfare of Rome so often evoked in his propaganda, Virgil is recalling to him with more urgency his duties and the expectations of the people about him. He is reminding the former triumvir of his past mistakes, exorting him to avoid them in the future, but he is also warning that these are not forgotten and that the anguish and resentment aroused by him in the past undermine the idealized image Virgil now offers of him and his political actions.

Of course, by mentioning Tityrus, ascribing to himself the authorship of that character (Tityre, te ... cecini, "Tityrus, I ... sang of you", v. 566), and sympathizing with the shepherd in the same poetic otium as guaranteed by a deus, Virgil is suggesting his own identification with Tityrus; ${ }^{17}$ already at Georg. 2. 485-489 he has reaffirmed his bucolic vocation by mentioning the protective shadow ( $\mathrm{O}$ qui me ... ingenti ramorum protegat umbra!, "please, protect me in the shadow of large branches", Georg. 2. 488-489) and has recalled the famous image of Tityrus patulae recubans sub tegmine fagi, "reclining beneath the shelter of a broad beech tree" (Ecl. 1. 2; cf. Georg. 4. 566). In the poet's declaring his earlier self to be audax, because he had dared throw the responsibility for confiscations in Octavian's face, with their load of pain, someone have read the 'palinode' of Virgil, who now, reviewing the facts and his judgments in those years, finds excessive his youthful boldness in the face of the great merits acquired by the new ruler of Rome. ${ }^{18}$ This interpretation, however, makes the poet undeniably narrow-minded, and the image of Virgil (who now, because of the power of the winner, denies even the limited autonomy he had shown in his youth,

${ }^{17}$ In this sense is generally understood the quotation of Tityrus (see POWELL [n. 1] 186), because even at $E c l$. 6. 4, the poet chooses for himself that name. But on the awkwardness in giving the same identity to all homonymous characters in the Eclogues see JENKINS, R.: Virgil and Arcadia. JRS 79 (1989) 26-39, esp. 38.

\footnotetext{
${ }^{18}$ See Powell (n. 1) 270-271.
} 
when Octavian was not so strong) looks decidedly bleak and difficult to accept for later readers of the poems, who don't deny his steadfast assent to Octavian's party.

With the initial dualism of the first Eclogue in the concluding lines of the Georgics, Virgil may, however, equally well identify himself with Meliboeus, not only because he cites a verse spoken by that character and, like him, speaks to Tityrus, but also because the first words of the unhappy shepherd contain a 'chiastic' disposition 'you / we / we / you' (meditaris / linquimus / fugimus / doces, vv. 1-5), repeated at Georg. 4. 559-566 in the presentation of the poet and Caesar (canebam / fulminat / dat / adfectat / me alebat / cecini. In this way, as in the first Eclogue, the poet takes on the dual role of both characters, with their stories and their conflicting emotions, and becomes again the spokesman of two opposite attitudes towards Octavian which evidently continued to divide the Roman people, even after the final victory over Anthony. He is now as audax as then, perhaps even more, in daring to remind the powerful lord of Rome of his past guilt and the resentment against him not yet appeased.

The features of the text, filled with a subtle but undeniable irony, orient one towards this ambiguous reading of the presentation of both Octavian and the poet. If the image of the powerful winner, who as a god fulminat in the East, echoes the praises of the kings in Alexandrian laudatory poems, ${ }^{19}$ even Georg. 4. 561-562 (victorque volentis / per populos dat iura, "and as a winner gives laws to willing nations") points to an anticipation of the Roman ethics enunciated by Anchises at Aen. 6. 851853 (tu regere imperio populos, Romane, memento... "you, Roman, remember to rule peoples with your power"); one cannot miss the disproportionate emphasis on the military operations of Octavian and the unusual assignment to a man of the most typical of Jupiter's features: fulminare seems in fact to conceal an ironic touch in its

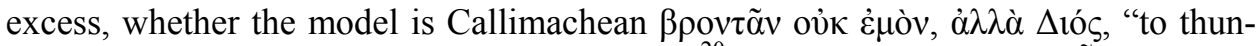
der is not mine, but of Zeus" (Aet. fr. 1.20 Pf), ${ }^{20}$ or Rhian. fr. 1.13 Pow (î̄ $\alpha \Delta \Delta$ ù $\beta \rho o-$ $\mu \varepsilon ́ \varepsilon 1$, "he thunders as Zeus"). ${ }^{21}$ Problematic in the same way is the expression, viam adfectat Olympo, "he prepares a path to heaven" (Georg. 4. 562), that can be read as an allusion to the ongoing deification of Octavian, in parallel with the announcement of Georg. 1. 24-42, but also as a hint at a huge ambition and a titanic v̈ $\beta p ı \varsigma^{22}$

Even the self-representation of Virgil appears insincere in the excessive degradation of the poet's image and life choice: ignobilis - it is true - can have the etymological meaning of 'not known' (or rather, in the active sense, 'that does not give notoriety'), and can recall the ideal of the secluded life longed for at Georg. 2. 485489 , so that the depreciation of the value of bucolic poetry could reflect the humble nature (humilis) of the genre and its characterization as a game (lusus). Yet the over-

${ }^{19}$ See ThOMAS I (n. 4) ad Georg. 1. 24-43, p. 73, who thinks mainly of the Lock of Berenice; THOMAS II (n. 4) ad Georg. 4. 560-561, p. 240; CADILI (n. 13) 18-91, esp. 18-37.

${ }^{20}$ THOMAS II (n. 4) ad Georg. 4. 560-561, p. 240.

${ }^{21}$ As Hollis (n. 4) 305, n. 1, and 306-308 suggests.

${ }^{22}$ This second interpretation, overshadowed by the possible meaning of adfectare, that Virgil uses in an ambiguous sense, could support the dependence of Georg.4. 561-562 on Rhian. fr. 1. 9 ff. Pow, with its negative characterization of the man who exalts himself by pretending to emulate Jupiter: cf. HOLLIS (n. 4) 306 . 
shadowing of the poet and his work is in any case exaggerated and gives the impression of a subtle irony. Moreover, in the course of the poem Virgil has shown himself well aware of the importance of his role as a didactic poet, even for Octavian. In short, in this anomalous ending appears ambiguous, and the dualism that it offers seems to sum up the oppositions presented in other key points of the poem, in accordance with the typical Virgilian thought, as we will see.

Inevitably, in fact, Virgil's distinction between felix and fortunatus comes to mind, in which the confrontation between literary genres (ambitious 'scientific' poetry and bucolic simplicity) extends to two life choices and two attitudes towards nature:

felix qui potuit rerum cognoscere causas

atque metus omnis et inexorabile fatum

subiecit pedibus strepitumque Acherontis avari:

fortunatus et ille deos qui novit agrestis,

Panaque Silvanumque senem Nymphasque sorores.

Georg. 2. 490-494

Blessed is he whose mind had power to find the causes of things and trample underfoot all terrors and inexorable fate and the clamour of devouring Acheron; but happy too is he who knows the gods of the countryside, knows

Pan and old Silvanus and the sisters Nymphs.

In contrast to the felix, who hopes to master the secrets of the world with the human reason and to find in this way freedom from fears, the fortunatus represents a fideistic acceptance of the natural rhythms and a confident abandonment to them, allowing the comprehension of nature's spirit, embodied by its gods, and granting perhaps the attainment of a true wisdom. If a reflection of these two attitudes can be glimpsed in the final $\sigma \varphi \rho \alpha \gamma i s$, in the contrast to the glorious and somewhat arrogant activity of Octavian and Virgil, it could be argued that the judgment of the poet, not expressed, but deducible from his constant praise of agricolae, is that these are the really lucky ones, who rely on nature and its gods and live away from ambitions and pains. This dualism, impossible to examine here, is the deep opposition between town and country, or between nature and history, always present at the mind of Virgil. The preference for a life outside the turmoil of contemporary events makes a ßío $\varsigma \pi \rho \alpha \kappa \tau 1 \kappa o ́ \varsigma$ a painful necessity for some, ensuring serenity for others (Octavian with his military campaigns assures for the poet his quiet existence), but condemning those who live this ßío $\pi \rho \alpha \kappa \tau \imath \kappa o ́ s$ to live in perpetual dissatisfaction (think of Aeneas, who would have remained in his homeland, rejecting a heroism imposed as a duty and felt as a perpetual renunciation).

That this is the veiled judgment by Virgil about Octavian and his choices is of course only a reconstruction, possible through the analysis of his Weltanschauung; but behind his confrontation with the future princeps there is another crucial dualism of the Georgics, that between Aristaeus and Orpheus. The interpretations of this celebrated episode are many, but central to our topic, it seems to me, is the theme of violence - which is painful but necessary for the triumph of life. A new swarm of bees is 
born only from a dead cow and Aristaeus must do violence to Proteus to know the reason for his punishment; in Orpheus' behaviour someone also has seen a violence toward nature, ${ }^{23}$ both in his victory, obtained with the power of poetry, over the laws of life and death when he regains Eurydice from Hades, and in drawing trees and taming wild beasts. ${ }^{24}$ This, however, does not seem right to me: the miraculous effects that he gets are the result of the power of poetry - the more compelling, the deeper the grief that inspires it - but there is in Orpheus no aggressive intention towards nature or the gods, and it is a tragic irony that his actions harm only himself and his beloved Eurydice. Rather, he is a victim of the violence of others (that of Aristaeus against Eurydice, which will result in the death of the girl, and that of Ciconum matres against him), and not by chance he is compared to the nightingale brutally deprived of her youngs by the durus arator:

\section{qualis populea maerens philomela sub umbra amissos queritur fetus, quos durus arator observans nido implumis detraxit.}

Even as the nightingale, mourning in the shadow, bewails the loss of her puppies, that a cruel ploughman, spying, has torn from the nest. ${ }^{25}$

The violence against nature is indeed a repeated theme in the Georgics: the farmer is violent while destroying a forest in order to obtain arable land, and his work is sometimes described in military terms, ${ }^{26}$ as an inevitable but cruel war. This is also the attitude of Aristaeus, who in many ways - as we know - embodies the ideal farmer. ${ }^{27}$

On the other hand, the theme of violence and the tension between those who adopt such behaviour and those who suffer or reject it are constant elements in Virgilian poetry: this is the thread that ties all the texts thus far examined: Ecl. 1, in which the brutality of confiscations destroys the bucolic world of Meliboeus and the possibility to make poetry (carmina nulla canam, "I will sing no songs", Ecl. 1. 77); Georg. 2. 490-494, in which the attitude of the felix (and of the 'scientific' poet, who dares 'attack' the secrets of nature) is described as violence (subiecit pedibus, "who trampled underfoot", Georg. 2. 492), while the knowledge of the fortunatus (and of the bucolic poet) is assigned to the peaceful relationship with the gods and the natural forces (deos qui novit agrestes, "he who knows the gods of the countryside", Georg. 2. 493). In the case of Orpheus and Aristaeus the violence of the first results in the winning strategy, but undeniably makes the character less sympathetic than the un-

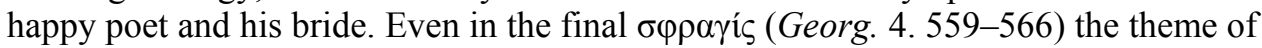

${ }^{23}$ Cf. Conte, G. B.: Virgilio. Il genere e i suoi confini. Milano $1984^{2}, 47$ sqq. I have difficulty accepting Conte's argument that in Orpheus' behavior there is violence toward nature.

${ }^{24}$ This is for example the interpretation of CONTE (n. 23) 47 sqq.

${ }^{25}$ Although interpreted as a positive characterization of strength and necessary determination (see POWELL [n. 1] 263-265), the epithet durus undeniably maintains a connotation of cruelty which leads the reader to sympathize with the innocent victim.

${ }^{26}$ Cf. POWELL (n. 1) 239-245.

${ }^{27}$ See CONTE (n. 23) 46-47 and 51-52, but see the discussion in GAGLIARDI, P.: Gravis cantantibus umbra. Studi su Virgilio e Cornelio Gallo. Bologna 2003, 104-110 and 113-114. 
violence appears, and the two attitudes are reflected in the real (but at the same time symbolic) figures of Octavian and Virgil: the hardness of the military operations of the former is in contrast to the intangible peace of the latter.

Is this perhaps the ultimate recognition, by the poet, in the immediate reality and in his own biography, of the inevitability of violence in life and history, the admission of the painful necessity of a force which, however, he can justify, but not intimately understand? To Octavian, victorious executor of fate, author of magnificent deeds and glorious achievements, Virgil continues to oppose the ideal of a sheltered and quiet life, far from the tumult of history and from the torments of human reason, where, should he try to explain the inexplicable, he would only discover his own limits. At the end of the poem, just as at the beginning of the Eclogues, and on a greater scale throughout the Aeneid, the problem remains the justification of history. Though one may rationally accept it, history leaves a lot of unresolved questions at the emotional level: thus, in sympathy for each person defeated is an underpinning criticism of the winners and their means of success, and pain for those who, guilty or innocent, have had to suffer because of them. Behind these judgments stands Octavian, in the balance at least possible after his ultimate victory and peace: the contradictions of power and the paradox of achievements obtained at the cost of so much evil join in his person, and he, loaded with lofty merits, but also with unforgivable errors and abuses, escapes a univocal judgment and is the synthesis of the irreducible oppositions of reality.

The thematic and conceptual complexes so far examined continued to haunt Virgil even in the Aeneid, where they will be further elaborated and where the reflection on the meaning and justification of history will become more dramatic and crucial. Activity and passivity, life in or out of the world, the violence of war as a fatal, but morally unacceptable necessity, sympathy for the defeated, all this finds place in the characterization of the protagonist, even before rather than in the structure of the poem. And if Aeneas embodies Augustus (an identification possible only occasionally and only in some respects, of course), he summarizes all the contradictions and ambiguities of the princeps and his power. Obviously, the poet's attitude towards Augustus is always clearly positive, when he talks about him and his divinity, or when he prophesies the new era that will ensue. There is a passage, however, that is particularly significant for its prominent position, in which these certainties seem at least scratched by an alternative vision of things. This is the most debated ending of the poem, the killing of Turnus by Aeneas, angry at the sight of the baldric of Pallas, after his hesitation as he looks at Turnus pleading for his life. It would be impossible to summarize here the critical positions on the behaviour of the hero - for some, a justified revenge for the young man who was brutally murdered and in keeping with the mandate entrusted to him by Evander, but for others, a ruthless ferocity that sweeps away any feeling of humanity. ${ }^{28}$ Beyond the possible readings, all of them motivated by the ambivalence of text and situation, there is an interesting repetition, as at the ending of the Georgics, of a dualistic scheme: here, however, roles and responsibilities are

\footnotetext{
${ }^{28}$ For at least a partial bibliography on this point cf. GAGLIARDI (n. 27) 245-277.
} 
mixed and make an ethical judgment difficult, if not impossible. It is beyond argument that the wrath of Aeneas is fully justified by his duties towards Pallas and Evander and by the previous behaviour of Turnus. The hero embodies Augustus here, in the parallel but inverted role of a 'fatherly' figure who avenges his son, and he is combined with Octavian as the young Caesar, always presented as a devoted son who avenged his father. So Octavian's behaviour, sometimes fierce over the years of his rise and of civil war, finds its justification: anger, motivated by the right reasons, is appreciated in the Roman mind, ${ }^{29}$ and the behaviour of Turnus, sometimes hateful, albeit driven by the influence of a Fury, makes his death an act of justice.

The structure of the conclusion, however, suggests a different and more complex interpretation of the scene. In Turnus one sees the gradual psychological transformation in the last book from a superbus blinded by rage to a man more and more aware of his destiny and more sympathetic: his hesitation and fear in the duel, especially after the intervention of the Dira, the slight wound, that forces him to fall on his knees, humiliated before his opponent, under the gaze of his friends, the wonderful supplication, an appeal to overcome the reasons for the conflict in the name of a higher humanity, and finally the very human indecision of Aeneas before seeing the baldric of Pallas: all this shifts the reader's attention to the defeated. No wonder, then, that the poet has his last words for this unsatisfied soul, connecting, certainly not by chance, Turnus' death to that of Camilla with the same verse (vitaque cum gemitu fugit indignant sub umbras, "and his injured life with a groan flees beneath the shadows", Aen. 11. 831 and 12. 952). The last image of Turnus is the same as the initial one of Aeneas in the poem (solvuntur frigore membra, "his limbs were loosened with cold", Aen. 1.92 and 12.951).

Problematic is instead the ultimate characterization of the protagonist and the words of Virgil for him, furiis accensus et ira / terribilis, "burning with fury and terrible in his anger" (12. 946-947), fervidus, "furious" (12. 951): Aeneas is here a furious Achilles, different not only from the pitying Achilles at the end of Iliad, but also from the trembling Odysseus of $O d .5 .297-312$, to whom he is assimilated in his first apparition at $1.92-101,{ }^{30}$ and from the thoughtful and mature hero he is throughout the poem. As fair and understandable is his anger, the very idea of leaving him with this ferocious image is indicative of the message the poet wants to communicate, that of the frailty of human nature and the ease with which it falls into excesses, undoing the achievements of balance and wisdom; because undeniably, even if justifiably, in his final reaction Aeneas is no different from the fury of Turnus in previous books, and is no longer the new hero, the bearer of a more human ethics, just as Octavian with his massacres in the triumviral period did not distinguish himself by humanity from the assassins of Caesar, whom he wanted to punish. ${ }^{31}$

\footnotetext{
${ }^{29}$ As has been shown by, among others, GALINSKI, K.: The Anger of Aeneas. AJPh 109 (1988) 321-348, esp. 323-324, 327-328.

${ }^{30}$ On the comparison between Od. 5. 297-312 and Aen. 1. 92-101, cf. GaGLIARDI, P.: O terque quaterque beati. Riflessioni su Aen. 1. 81-101. RAAN 75 (2008-2011) 91-106.

${ }^{31}$ On this matter, cfr. GAGLIARDI: Gravis (n. 27) 272-277 and GAGLiARDI, P.: Pallante, Lauso e l'ira di Enea. Aufidus 49 (2003) 21-59, esp. 56-59.
} 
Apart from Virgil's ethical judgment on the rightness of his last action, the final characterization of Aeneas/Augustus thus provides a warning not to forget the past evils: in the same way, the confiscations are recalled, at the end of the Georgics, with the echo of Ecl. 1. 1, to show the ancient shadows behind the lights of the winner. This is a constant attitude of Virgil towards Octavian, when he reflects on the new course of history; it is the sign of a wound that his generation has experienced and that makes the acceptance of the new regime not unconditional; it continues to show both the pain it has cost and concern it raises for future risks. The awareness of human frailty casts a gloomy shadow over the future. Those, too, who claim to be gods can fall victim to power. The pain of the past weighs on the future, the suffering of man must exist but can't be justified and accepted. The judgment about Octavian is, for Virgil, the judgment of history, for which the new ruler, like Aeneas, is an executor: this judgment understands the reasons for fate and the inevitability of its fulfillment at any price, but also receives the voice of the victims, the unanswered question of those who will not be compensated for their pain. This is the dilemma of the whole poem, indeed of the whole of Virgil's work: at its core is a broken vision of reality, the result of the upheavals that the generation straddling the line between the last civil wars and the Augustan regime had to live, without being able to overcome them in their own minds. Hence the difficulty of an unambiguous opinion, the inability to see the world only one way; hence the extraordinary broad-mindedness of Virgil and the deep humanity that makes all of his characters great. Hence one finds a sensitivity, heightened by recent experience, an ability to understand and to represent the torments of the winners themselves, their sacrifices, and a need to be cruel beyond their will. Hence, above all, one sees Virgil's main concern to remember the defeated, overwhelmed by the inevitability of fate, and to raise them to share the stage with the winners, a memento, especially in the ending of the two poems, of past sufferings and evils upon which the promised happiness is based.

From Meliboeus to Orpheus, from Virgil in his Neapolitan otium to Turnus fleeing into Hades, from the first to the last image of his work, the poet always reserves for the victi tristes his last word of pity: in this, however, is also the admonition to Octavian, in contrast to his idealized image and the alleged happiness of the new era inaugurated by him, not to forget the past with its mistakes and sorrows. This shade, constant in the conclusions, reminds contemporaries of the fragility of human nature (it is not by chance that all the works of Virgil end with a shadow, whether the word umbra or - in the Georgics - with a reference to the shading cover (sub tegmine fagi) of Tityrus' beech). But this shade has much to say also to the moderns about the relationship between the Augustan poets and the regime, and about the limits of their consent to it.

Paola Gagliardi

Università degli Studi della Basilicata

paolagagliardi@hotmail.com 